\title{
Hydrogen: Technologies, Policies and Challenges
}

\author{
Zhang Jun ${ }^{1, a^{*}}$ Ji Lucheng ${ }^{2, b}$ Jin Bo ${ }^{1, c}$ \\ ${ }^{1}$ Department of Energy Information Research, Wuhan Documentation and Information Center \\ of Chinese Academy of Sciences, China \\ ${ }^{2}$ School of Aerospace Engineering, Beijing Institute of Technology, China \\ azhangjun@mail.whlib.ac.cn, ${ }^{\text {bjilc@bit.edu.cn, }{ }^{2} j i n b @ m a i l . w h l i b . a c . c n ~}$ \\ Corresponding author: zhangjun@mail.whlib.ac.cn, +86 2787314525
}

Keywords: hydrogen, hydrogen economy, fuel cell, r\&d, policy, technology

\begin{abstract}
Hydrogen energy has been considered as a clean alternative energy source substituting fossil fuels. Many countries consider it as the ultimate solution to the energy and environmental problems, even draw up the blueprint of "hydrogen economy" and heavily invest for research and development. However, after decades of research, the hydrogen energy technologies are still being prospective and explored, and haven't been put into large scale production by now. This article begins with expatiation on the essence of hydrogen energy, makes analysis of various big challenges for hydrogen energy technologies, and reaches the conclusion that we should hold the rational and cautious attitude towards hydrogen energy source because the transition to hydrogen economy of unclear prospect must pay a very high cost, which is unbearable for the social and economic development status of developing countries.
\end{abstract}

\section{Introduction}

Hydrogen (symbol H) is the most abundant chemical element in the known universe. On earth, in addition to existence in organic compounds, hydrogen mostly exists in the form of water after combining with oxygen. Therefore, just as solar energy, hydrogen leaves us an impression of "inexhaustible" resource. The hydrogen gas $\left(\mathrm{H}_{2}\right)$ formed by element hydrogen is a highly flammable substance with high energy density. The heat release per unit mass hydrogen gas is three times of heat release per unit gasoline. Also the final product of hydrogen gas is only water, without emission of direct pollutants. Apparently it is an absolutely clean fuel. Since the fossil fuel energy is an unsustainable resource which emits carbon dioxide and pollutants, and renewable energy sources do not have stable supplies in large scale and thus being dubious, the hydrogen energy is commonly regarded as a candidate energy source that is an ultimate solution to energy and environmental problems.

\section{Blueprint and R\&D of Hydrogen Economy}

United States is one of the earliest countries which proposed the hydrogen program and hydrogen energy economy blueprint. In 1990 the Hydrogen Research, Development, and Demonstration Program Act of 1990 was enacted and the U.S. Department of Energy (DOE) has been funding hydrogen energy research projects. After inauguration in 2001, the former President Bush showed much interest in developing hydrogen energy. DOE convened the "National Hydrogen Vision Meeting" and released the report A National Vision of America's Transition to a Hydrogen Economy: To 2030 and Beyond, putting forward the ideas of vigorous development of hydrogen energy and gradual transition to the hydrogen economy based on hydrogen energy. In the next year, DOE initiated the National Hydrogen Energy Roadmap to present the measures and policies, as well as the steps and methods for transition to hydrogen economy etc. In 2003, DOE issued the Hydrogen Posture Plan: An Integrated Research, Development and Demonstration Plan, clarifying the phases and timeframe of transitioning to hydrogen economy: technology development phase (RD\&D, 
2000-2015), initial market penetration phase (2010-2025), infrastructure investment phase (2015-2035) fully developed market and infrastructure phase (realization of the hydrogen economy, 2025-2040), which are four overlapping and related phases with goal of realizing the transition to hydrogen economy in 2040. For this purpose, former President Bush announced plans to appropriate $\$ 1.2$ billion to develop hydrogen fuel cell cars and the investments of Federal Government in technological research and development are increasing at a steady pace.

However, not long after President Obama inaugurated in 2009, he sharply reduced the Federal budget for hydrogen fuel cell car research of FY2009 from 169 million dollars to 68.2 million. Although this proposal was rejected by the Congress in September 2009, President Obama still announced in February 2009 that the appropriation of funds to the hydrogen fuel cell car would be eliminated. From the perspective of United States' technological funding decision-making mechanism, this was not solely Obama's individual will, but also results from the prospect analysis of engineering and scale applications of hydrogen energy technologies and the review of the hydrogen economy. According to statistics, the U.S. Federal Government's funding for hydrogen energy and fuel cell was declining in recent three years. This indicated that the hydrogen economy plan advocated by the Bush administration was finally suspended.

European Union is also an active advocator of hydrogen economy. In June 2003, the European Commission ever issued the report Hydrogen Energy and Fuel Cells: a vision of our future, which proposed that the Europe will transition to the hydrogen-oriented economy in 2050 and define the roadmap of three phases of research, development and demonstration actions in the short term (2000-2010), medium term (2010-2020) and long term (2020-2050). According to statistics, from 1986 until now, European Union provided totally 550 million euro for about 200 hydrogen and fuel cell technology programs, which accounts for only a very small proportion of R\&D investment in the energy fields (the energy R\&D budgets of EU in 2007-2013 is 2.35 billion euro).

In the "New Sunshine Program" in 1993, Japan planned to invest 3 billion dollars for key technologies R\&D of hydrogen energy up to 2020. On June 2003, the Ministry of Economy, Trade and Industry issued the Japan's Approach to Commercialization of Fuel Cell / Hydrogen Technology, planning to own 5 million fuel cell vehicles and construct 10,000MW of stationary fuel cell power generation system in 2020; and own the 15 million fuel cell vehicles and construct $12,500 \mathrm{MW}$ of stationary fuel cell power generation system in 2030.

South Korea established the "Hydrogen Energy R\&D Center" in 2003 and put forward a ten-year hydrogen development program, divided into three phases: elementary research phase in 2003 2005, demonstration phase in 2006 2008, and popularization phase in 2009 2012. Other countries such as Canada and Australia, also proposed their hydrogen economy development roadmap in 2002-2004.

The hydrogen energy technology research in China can be dated back to early 1970s. Since the "Ninth Five-Year Plan", the National Natural Science Foundation of China (NSFC), the Ministry of Science and Technology of P.R.C. (MOST), China Academy of Science (CAS) and some provincial and municipal science and technology administrations funded some research programs. During the Tenth Five-Year Plan, CAS and MOST jointly developed big research programs of fuel cells and hydrogen vehicles. In the National Medium and Long Term Program for Science and Technology Development (2006-2020) and the Energy Development Eleventh Five-Year Plan, the hydrogen energy is emphasized as one of the key advanced technologies.

As stated above, among the actual investments and industrial development of these countries, the percentage of hydrogen energy technology research funds is still very low and until now it hasn't realized industrial production in large scale, so the hydrogen energy technologies are still being prospective and explored and the realization of hydrogen economy is improbable in the predictable future. 


\section{Hydrogen Technologies}

Hydrogen technologies include hydrogen production, hydrogen storage, hydrogen transport and fuel cell technologies etc.

Hydrogen production is the first key part for use of hydrogen energy. Hydrogen is not available on earth in the free form, but in compounds with other elements. Hence, the hydrogen is a secondary energy like electricity, and it must be produced by proper technical means and consuming other primary or secondary energy sources.

As far as we know today, hydrogen can be produced using fossil fuels, such as coal, natural gas or petroleum, or by chemical, biological, electrolysis and photolysis processes etc of water. The former technologies must be based on the fossil energy reserve, and the latter processes mainly depend on the secondary energy - electricity, in addition to unknown feasibility of hydrogen production by direct use of solar energy. Considering the processes, materials, energy sources and efficiency of existing hydrogen production technologies, except using the renewable energy sources, the other technologies directly or indirectly give off a large amount of carbon dioxide or pollutants. These mean that it is an undue idea to emphasize only on the advantages of inexhaustibility, high efficiency and no emission of gases of hydrogen. Moreover, existing hydrogen production technologies and processes are still uncompetitive.

Table 1 Main hydrogen production methods

\begin{tabular}{|c|c|c|c|c|}
\hline Main methods & Process & Material & Energy source & $\begin{array}{l}\mathrm{CO} 2 \\
\text { emission }\end{array}$ \\
\hline \multirow{5}{*}{$\begin{array}{l}\text { thermal } \\
\text { methods }\end{array}$} & steam reforming & natural gas & $\begin{array}{l}\text { high temperature } \\
\text { steam }\end{array}$ & yes \\
\hline & thermochemical & water & high temperatures & no \\
\hline & & & reactor & \\
\hline & gasification & $\begin{array}{l}\text { coal, } \\
\text { biomass }\end{array}$ & $\begin{array}{l}\text { high temperature high } \\
\text { pressure steam and } \\
\text { oxygen }\end{array}$ & yes \\
\hline & thermolysis & biomass & $\begin{array}{l}\text { high temperature } \\
\text { steam }\end{array}$ & yes \\
\hline \multirow{4}{*}{$\begin{array}{l}\text { electrochemical } \\
\text { methods }\end{array}$} & electrolysis & water & $\begin{array}{l}\text { electricity generated } \\
\text { by renewable energy, } \\
\text { hydroelectric power } \\
\text { and nuclear power }\end{array}$ & no \\
\hline & electrolysis & water & $\begin{array}{l}\text { coal or electricity } \\
\text { generated by natural } \\
\text { gas }\end{array}$ & yes \\
\hline & photoelectrochemical & water & direct sunlight & no \\
\hline & photobiological & $\begin{array}{l}\text { water and } \\
\text { algae }\end{array}$ & direct sunlight & no \\
\hline \multirow{2}{*}{$\begin{array}{l}\text { biological } \\
\text { methods }\end{array}$} & anaerobic digestion & biomass & heat from & yes \\
\hline & $\begin{array}{l}\text { microbial } \\
\text { fermentation }\end{array}$ & biomass & $\begin{array}{l}\text { heat from } \\
\text { temperature }\end{array}$ & yes \\
\hline
\end{tabular}

Now the hydrogen production using fossil fuels has already been commercialized and globally 50 million metric tons of hydrogen are produced. But they are seldom used as fuel, but the materials for manufacture of fertilizers $(50 \%)$, oil refining (35\%) and methanol $(8 \%)$.

Hydrogen storage is the second key part for use of hydrogen energy. Because the volume per unit mass hydrogen gas is much larger than that per unit mass gasoline or natural gas, if it is to be used as 
fuel, the hydrogen gas must be pressurized or liquefied. According to state of hydrogen in store, the main hydrogen storage methods include metal hydride, liquid hydrogen, compressed hydrogen etc. Hydrogen storage is process of energy storage and release, and also a typical process of energy consumption.

Energy conversion is the final procedure of hydrogen use. Hydrogen gas can be directly burned to drive vehicles, but without obviously higher efficiency than conventional fuels such as gasoline, so the internal combustion engine must be altered. One approach is highly appreciated, that is, hydrogen gas is converted to be electric energy through electrochemical catalytic reactions in fuel cells, which avert the restriction of Carnot cycle, thus having high conversion efficiency.

There are a great many varieties of fuel cells, which are divided into polymer electrolyte membrane fuel cell (PEMFC), alkali fuel cell (AFC), solid oxide fuel cell (SOFC) and molten carbonate fuel cell (MCFC) according to different electrolytes. Thus far, the fuel cell technologies still hasn't realized the stable industrial production and use.

\section{Challenges for Hydrogen Economy}

Hydrogen energy has its advantages, but there are also many big challenges in science, engineering, economy and politics.

For hydrogen production, the physical and chemical properties of hydrogen determine that the energy needed for hydrogen production is always more than the energy it releases no matter what kind of methods and materials are used. As a result, in order to obtain sufficient quantities of hydrogen, there must be abundant and cheap primary energy sources to meet the need of production and be used as materials. Coal and natural gas are ideal materials for hydrogen production, but the technologies are complex and will emit greenhouse gases. The hydrogen production technology by biomass isn't mature yet, and it may also bring about negative effects on agricultural production and land use. The hydrogen production by electrolysis of water is mature and easy, but very large amounts of electric power will be consumed. Use of renewable energy sources such as solar energy and wind energy are ideal candidates, but the problems of low efficiency and high cost must be solved first. Hydrogen production by the thermochemical process using nuclear energy is feasible in theory, but the currently commercial nuclear reactors are unsuitable for hydrogen production. To sum up, the lack of low cost and large scale commercial hydrogen production method is the biggest bottleneck of hydrogen energy development.

Today's hydrogen storage technologies are far from attaining the goals of safety, high efficiency, small volume, light weight, low cost, and high density. This is a long way to go before practical use of hydrogen. Low density and large volume of hydrogen gas make it difficult to find an on-vehicle hydrogen storage method enabling adequate driving mileage. Although compressed hydrogen and liquid hydrogen are commercially viable, the problems of safety and economy haven't been solved. The flammability and explosivity of hydrogen gas prevent it from being accepted by the society.

As for the carrier of hydrogen energy, fuel cell is deemed as the most promising conversion technology, but up to now, the stable industrial and scale production and use of fuel cell is still unrealized. High cost, instability, low reliability, inadequate durability and heavy dependence on metal catalysis materials provide the bottlenecks of immature technology, insufficient resource and environmental damage for use of fuel cells in large scale, so that it is short of technical supports by high efficiency use after low efficiency hydrogen production.

The biggest advantage of hydrogen energy is that it gives off no greenhouse gases. However, as reported by researches, if fossil fuels such as coal, petroleum and natural gas are fully replaced by hydrogen fuel, it is estimated about $10 \% \sim 20 \%$ of hydrogen will leak and enter into the stratosphere and be oxidized into water molecules, thus resulting in lower temperature of stratosphere, interfering with the chemical process of ozone formation, and further producing a larger ozone holes which lasts longer in north pole and south pole of Earth.

Even though the technical issues are finally solved, the realization of hydrogen economy needs large scale constructions of infrastructure for hydrogen production, sale and transport and replaces 
the petroleum-centered infrastructure system that have been constructed in one hundred years. This will surely incur tremendous social and economic costs and encounter various conflicts from interested parties. In the international relations, it is difficult to predict the influences of hydrogen economy on the existing energy production and consumption, input and output patterns.

As far as today's energy and environmental problems are concerned, despite that many countries invested in research and development of hydrogen technologies and drew up hydrogen economy blueprints, no country regards it as the only energy solution and gives it the absolute priority and persistent exploration and demonstrations. They are exploring and researching other energy technologies in the meantime, without very much attention to hydrogen energy. Nuclear fusion, renewable energy sources and clean alternative fuels are the possible convincing competitors of hydrogen energy. For example, if the fuel cell technologies of pure electric vehicles take the lead in making breakthrough, no doubt that the hydrogen economy will be given up halfway.

\section{Conclusions}

Blueprints of hydrogen economy are not drawn in the early period of this century. As early as 1970s, optimistic prediction told that the hydrogen economy would come true in the year 2000. A research program in 1976 funded by US National Science Foundation pointed out the main technical concerns of hydrogen economy, including environment friendly large scale low cost commercial hydrogen production technology, safe transportation and storage, high hydrogen storage capacity on vehicle, and durable, reliable and cheap fuel cells etc. Thirty years passed, and although great progress has been made in the microscopic fields such as hydrogen production, storage, transport as well as fuel cell, these concerns haven't made substantial breakthrough. The enthusiasm of developed countries for hydrogen economy in the beginning of this century calms down now. All these reveal the difficulties of realizing hydrogen economy.

From the analysis above, it can be found that many barriers of hydrogen economy are related to the basic properties of hydrogen, which isn't the mainstream energy source and will hardly be accepted by public as an economic and safe energy carrier. This can't be changed solely by political will or high investment in researches.

Therefore, we suggest that a rational and cautious attitude towards the hydrogen energy source must be hold because the transition to hydrogen economy of unclear prospect must pay a very high cost, which is unbearable for the social and economic development status of developing countries. We shouldn't invest blindly in the research and development of hydrogen energy just due to its advantages or being once advocated by foreign countries; likewise, we shouldn't do nothing just owing to a series of challenges it faces. Hydrogen energy and fuel cell cover a huge technical system and play an important role in the development of science and technology. For China, military use, space development, energy supply to remote areas, integration with renewable energy sources, family or small scale commercial combined heat and power (CHD) etc., all these provide special demands for hydrogen energy technologies. What we need to do is to clarify the development paths and reasonable orientation, and decide on the prior development directions for hydrogen energy use.

\section{References}

[1] Richard A.Muller: A Pollution-Free Hydrogen Economy? Not So Soon.(2003), vailable:http://muller.lbl.gov/tressays/18_hydrogen.html

[2] U.S. National Research Council. The hydrogen economy: Opportunities, costs, barriers, and R\&D needs, (2004). . [Online]. Available:http://www.nap.edu/books/0309091632/html

[3] Bossel U., Eliasson B., and Taylor G., The future of the hydrogen economy: Bright or bleak? Proc. Eur. Fuel Cell Forum, 2003

[4] Zhang J, Li XC, etc., International Energy Policy and Technologies Progress, Science Press, (2008) 
[5] Royle M., Willoughby D., The safety of the future hydrogen economy, Process Safety and Environmental Protection, 89(2011)452-462

[6] Andrews J., Bahman Shabani B., Re-envisioning the role of hydrogen in a sustainable energy economy, International Journal of Hydrogen Energy, 37(2012)1184-1203

[7] Hughes N., Agnolucci P., Hydrogen Economics and Policy,Comprehensive Renewable Energy, $4(2012) 65-95$ 